\title{
Response of cucumber to timing of fertilizer application in southwest Nigeria
}

\author{
F. O. Odeleye ${ }^{1,3,4}$, O. M. O. Odeleye ${ }^{2}$, J. K. Vessey ${ }^{3}$, Z. Dong ${ }^{3}$, and H. N. Ebuzome ${ }^{1}$ \\ ${ }^{1}$ Department of Crop Protection and Environmental Biology, University of Ibadan, Nigeria; \\ ${ }^{2}$ National Horticultural Research Institute, Jericho, Idi-Ishin, Ibadan, Nigeria; and \\ ${ }^{3}$ Department of Biology, Saint Mary's University, Halifax, Nova Scotia, Canada B3H 3 C3. \\ Received 15 June 2006, accepted 29 September 2006.
}

\begin{abstract}
Odeleye, F. O., Odeleye, O. M. O., Vessey, J. K., Dong, Z. and Ebuzome, H. N. 2006. Response of cucumber to timing of fertilizer application in southwest Nigeria. Can. J. Plant Sci. 86: 1391-1394. A field trial was conducted at the experimental farm of the Department of Crop Protection and Environmental Biology, University of Ibadan, Nigeria, to determine the growth and yield response of cucumber (cv. Poinsett) to timing of fertilizer application. Fertilizer (20:10:10), at the rate of $150 \mathrm{~kg} \mathrm{~N} \mathrm{ha}^{-1}$, was applied at: planting, 3 weeks after planting (WAP) and 6 WAP. Similarly, split applications were given at planting +3 WAP, at planting + $6 \mathrm{WAP}$ and at $3 \mathrm{WAP}+6 \mathrm{WAP}$. The experimental design was a randomized complete block with seven treatments (six fertilizer application treatments plus a non fertilizer control) and four replications. Means were separated using Duncan's Multiple Range Test at the 5\% level of significance. In general, plants that were fertilized performed better than control plants in terms of vegetative growth and yield. A split application at $3 \mathrm{WAP}+6 \mathrm{WAP}$ performed the best in terms of vegetative growth and fruit yield. Fertilizer applied once-over at 6 WAP was the least beneficial; application of fertilizer once-over at planting, or a split application at planting $+3 \mathrm{WAP}$, resulted in a high level of vegetative growth but lower fruit yield compared with the split application at $3 \mathrm{WAP}+6 \mathrm{WAP}$.
\end{abstract}

Key words: Cucumber, N-P-K., time of application, vegetative growth, fruit yield

Odeleye, F. O., Odeleye, O. M. O., Vessey, J. K., Dong, Z. et Ebuzome, H. N. 2006. Réaction du concombre au moment de l'application des engrais dans le sud-ouest du Nigeria. Can. J. Plant Sci. 86: 1391-1394. Les auteurs ont procédé à un essai en pleine terre à la ferme expérimentale du département de phytoprotection et de biologie environnementale de l'Université d'Ibadan, au Nigeria, pour mieux voir comment la croissance et le rendement du concombre (cv. Poinsett) réagissent au moment de l'amendement. Pour cela, ils ont appliqué $150 \mathrm{~kg}$ de N par hectare d'engrais (20:10:10) à la plantation, trois semaines après cette dernière et six semaines plus tard. Ils ont aussi procédé à des applications fractionnées à la plantation et trois semaines plus tard, à la plantation et six semaines plus tard, et trois semaines ainsi que six semaines après la plantation. L'expérience s'est déroulée en blocs aléatoires complets avec sept traitements (six applications d'engrais plus un témoin non bonifié) et quatre répétitions. Les moyennes ont été séparées d'après le test à gamme multiple de Duncan à un seuil de signification de $5 \%$. Dans l'ensemble, les plants recevant de l'engrais donnent de meilleurs résultats que les plants témoins pour ce qui est de la croissance végétative et du rendement. L'application fractionnée trois et six semaines après la plantation donne les meilleurs résultats tant pour la croissance que pour le nombre de fruits. L'application d'engrais une seule fois six semaines après la plantation s'avère la moins bénéfique; l'application unique à la plantation ou l'application fractionnée à la plantation et trois semaines plus tard donnent la meilleure croissance mais pas autant de fruits que l'application fractionnée trois et six semaines après la plantation.

Mots clés: Concombre, N-P-K, moment de l'application, croissance végétative, rendement fruitier

Cucumber (Cucumis sativus L.) is an important vegetable crop grown world wide (Burkill 1985). It is a warm season crop, which grows best at temperatures ranging between 24 and $29^{\circ} \mathrm{C}$ in Nigeria. In North America, cucumber grows best at sunny locations with fertile, well drained soils (Drost and Hefelbower 2004). Cultivation of cucumber in Canada and the United States requires the incorporation of organic matter and a complete N-P-K fertilizer before planting. In addition, a side dressing of nitrogen (34-0-0) is recommended when the vines develop runner just before flowering for optimum performance of the crop (Drost and Hefelbower

\footnotetext{
${ }^{4}$ Present address: Department of Biology, St. Mary's University, Halifax, Nova Scotia, Canada (e-mail: gbengaodeleye2@yahoo.com).
}

2004). The importance of fertilizer application to cucumber has also been reported (Kano et al. 2001; Ruiz and Romero, 2002; Moreno et al. 2003; Jass-Chaverria et al. 2005). Cucumber performed optimally in well-drained, fertile soil but yields were higher on heavier soils when moisture was dependent on rainfall (Burkill 1985).

In Nigeria, cucumber is a relatively recent addition to the diet. Apart from eating cucumber raw or in salad mixes, cucumber leaf juice has medicinal uses. The leaf juice is emetic and is used to treat dyspepsia in children (Messien 1988). Very little local research has been conducted on cucumber and so there is dearth of literature on its fertilizer

Abbreviations: WAP, weeks after planting 


\begin{tabular}{lcccc}
\hline Table 1. Effect of timing of fertilizer application on vegetative characteristics of cucumber at Ibadan, Nigeria in 2004 & $\begin{array}{c}\text { No. of } \\
\text { Treatment }\end{array}$ & $\begin{array}{c}\text { Stem height } \\
\left(\mathrm{cm} \mathrm{plant}^{-1}\right)\end{array}$ & $\begin{array}{c}\text { No. of } \\
\text { nodes plant }^{-1}\end{array}$ & $\begin{array}{c}\text { No. of } \\
\text { branches plant }^{-1}\end{array}$ \\
\hline Planting & $36.75 a b$ & $77.25 a$ & $24.25 a$ & $2.00 c$ \\
3 WAP & $52.25 a b$ & $76.25 a$ & $19.00 a b$ & $2.50 b c$ \\
6 WAP & $35.00 a b$ & $70.00 a b$ & $21.25 a b$ & $2.75 b$ \\
3 + 6 WAP & $53.00 a$ & $70.00 a b$ & $21.00 a b$ & $3582.00 a$ \\
P + 3 WAP & $42.25 a b$ & $76.25 a$ & $21.00 a b$ & $2.00 c$ \\
P + 6 WAP & $45.50 a b$ & $78.75 a$ & $23.50 a b$ & $2.75 b$ \\
Control & $26.50 b$ & $50.25 b$ & $17.00 b$ & $2.00 c$ \\
\hline
\end{tabular}

zPlanting- fertilizer applied once-over at planting

$3 \mathrm{WAP}$, fertilizer applied once-over at $3 \mathrm{wk}$ after planting.

6 WAP, fertilizer applied once-over at $6 \mathrm{wk}$ after planting.

$3+6$ WAP, split application of fertilizer at 3 and $6 \mathrm{wk}$ after planting.

$\mathrm{P}+3 \mathrm{WAP}$, split application of fertilizer at planting and $3 \mathrm{wk}$ after planting.

$\mathrm{P}+6 \mathrm{WAP}$, split application of fertilizer at planting and $6 \mathrm{wk}$ after planting.

Control, no fertilizer applied.

$a-c$ Means followed by same letter(s) within a column are not significantly different at the $5 \%$ level of significance (Duncan's test).

\begin{tabular}{|c|c|c|c|c|c|}
\hline Treatment $^{\mathbf{z}}$ & $\begin{array}{l}\text { Leaf dry weight } \\
\left(\mathrm{g} \mathrm{plant}^{-1}\right)\end{array}$ & $\begin{array}{l}\text { Stem dry weight } \\
\left(\mathrm{g} \mathrm{plant}^{-1}\right)\end{array}$ & $\begin{array}{l}\text { Root dry weight } \\
\quad\left(\mathrm{g}_{\text {plant }}{ }^{-1}\right)\end{array}$ & $\begin{array}{l}\text { Fruit dry weight } \\
\quad\left(\mathrm{g} \mathrm{plant}^{-1}\right)\end{array}$ & $\begin{array}{c}\text { Total dry weight } \\
\left(\mathrm{g}_{\text {plant }}{ }^{-1}\right)\end{array}$ \\
\hline Planting & $19.46 a$ & $17.60 a$ & $3.42 a b$ & $20.38 b$ & $25.47 a b$ \\
\hline $3 \mathrm{WAP}$ & $17.53 a$ & $14.83 a$ & $6.15 a b$ & $19.61 b$ & $22.60 a b$ \\
\hline 6 WAP & $9.73 b$ & $12.38 a b$ & $2.44 b c$ & $5.43 d$ & $13.13 c$ \\
\hline $3+6 \mathrm{WAP}$ & $19.26 a$ & $19.11 a$ & $8.82 a$ & $42.19 a$ & $29.54 a$ \\
\hline $\mathrm{P}+3 \mathrm{WAP}$ & $15.50 a b$ & $13.62 a b$ & $2.71 b c$ & $10.76 c$ & $18.45 b c$ \\
\hline $\mathrm{P}+6 \mathrm{WAP}$ & $20.48 a$ & $12.37 a b$ & $3.63 b c$ & $11.75 c$ & $25.00 a b$ \\
\hline Control & $9.53 b$ & $5.90 b$ & $1.55 c$ & $6.39 d$ & $11.69 c$ \\
\hline
\end{tabular}

zPlanting, fertilizer applied once-over at planting.

3 WAP, fertilizer applied once-over at 3 weeks after planting.

6 WAP, fertilizer applied once-over at 6 weeks after planting.

$3+6$ WAP,-Split application of fertilizer at 3 and 6 weeks after planting.

$\mathrm{P}+3 \mathrm{WAP}$, split application of fertilizer at planting and 3 weeks after planting.

$\mathrm{P}+6 \mathrm{WAP}$, split application of fertilizer at planting and 6 weeks after planting.

Control, no fertilizer applied.

$a-d$ Means followed by same letter(s) within a column are not significantly different at the $5 \%$ level of significance. (Duncan's test).

requirements in Nigeria. Ekwu et al. (2000) reported that application of N-P-K (20:10:10) fertilizer at the rate of 150 $\mathrm{kg} \mathrm{N} \mathrm{ha}{ }^{-1}$ is used by farmers on cucumber in southern Nigeria. The time of fertilizer application, either once-over or in split applications, might influence the ultimate yield of cucumber as is the case in North America. This research was conducted to determine the best timing of fertilizer application in cucumber production in southwest Nigeria.

\section{MATERIALS AND METHODS}

A plot measuring $10.5 \mathrm{~m} \times 13.0 \mathrm{~m}$ was marked out and used on the experimental farm of the Department of Crop Protection and Environmental Biology, University of Ibadan, Nigeria, in 2004. The area was divided into four blocks $(10.5 \mathrm{~m} \times 2.8 \mathrm{~m}$ each) with $0.6 \mathrm{~m}$ border between successive blocks. Each block was divided into seven smaller equal plots $(1.5 \mathrm{~m} \times 2.8 \mathrm{~m})$ to which were randomly assigned seven treatments using a table of random numbers. The seven treatments were once-over fertilizer application at: planting, $3 \mathrm{WAP}$, or $6 \mathrm{WAP}$, and split applications at planting $+3 \mathrm{WAP}$, planting $+6 \mathrm{WAP}, 3 \mathrm{WAP}+6 \mathrm{WAP}$, and a control (no fertilizer). The experiment was laid out as a randomized complete block design with seven treatments and four replicates. The soil at the experimental site was an alfisol, and degraded due to continuous cultivation over several years. A soil test done before experimentation showed low levels of nitrogen, phosphorus and potassium.

Fertilizer, N-P-K (20:10:10) was applied at the rate of 150 $\mathrm{kg} \mathrm{N} \mathrm{ha}{ }^{-1}$, the rate being used by farmers in southern Nigeria (Ekwu et al. 2000). At this rate, $750 \mathrm{~kg}$ of fertilizer was required for 1 ha of land. Each small plot received 315 $\mathrm{g}$ of fertilizer. Half of this amount (i.e. 157.5g) was applied twice to plots that received the split application treatment. Fertilizer was applied as a side dressing.

\section{Planting}

Cucumber seed (cv. Poinsett) was sown on 2004 Aug. 27, at the rate of three seeds per hole at a spacing of $70 \mathrm{~cm} \times 70$ $\mathrm{cm}$. Fertilizer was applied to those plots that were designated to be fertilized at planting. The seedlings were thinned to one plant per stand $4 \mathrm{~d}$ after emergence. The first weeding was done 2 WAP. Further fertilizer application to appropriate plots was done thereafter, as required. The second and final weeding was done 4 WAP. 
Table 3. Effect of timing of fertilizer application on yield of cucumber at Ibadan, Nigeria, in 2004

\begin{tabular}{lll}
\hline Treatment $^{\mathbf{z}}$ & $\begin{array}{c}\text { No. of fruit } \\
\text { plant }^{-1}\end{array}$ & $\begin{array}{c}\text { Fruit fresh weight } \\
\left(\mathrm{g} \mathrm{plant}^{-1}\right)\end{array}$ \\
\hline Planting & $2.25 a b c$ & $518.20 a$ \\
3 WAP & $2.50 a b$ & $453.10 a b$ \\
6 WAP & $1.50 b c$ & $336.60 a b$ \\
3 + 6 WAP & $3.25 a$ & $554.00 a$ \\
P + 3 WAP & $1.75 b c$ & $515.40 a b$ \\
P + 6 WAP & $2.00 b c$ & $386.60 a b$ \\
Control & $1.25 c$ & $153.80 b$ \\
\hline
\end{tabular}

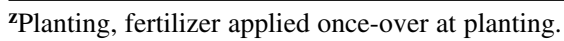

3 WAP, fertilizer applied once-over at 3 weeks after planting.

6 WAP, fertilizer applied once-over at 6 weeks after planting.

$3+6$ WAP, split application of fertilizer at 3 and 6 weeks after planting.

$\mathrm{P}+3 \mathrm{WAP}$, split application of fertilizer at planting and 3 weeks after planting.

$\mathrm{P}+6 \mathrm{WAP}$, split application of fertilizer at planting and 6 weeks after planting.

Control, no fertilizer applied.

$a-c$ Means followed by same letter(s) within a column are not significant-

ly different at the $5 \%$ level of significance. (Duncan's test).

\section{Harvesting and Data Collection}

Plants were sampled only at maturity at 8 WAP. Four plants were sampled per treatment, taking one plant from each replicate. For each plant harvested, the following growth and yield parameters were measured: leaf area $\left(\mathrm{cm}^{2}\right)$, stem height $(\mathrm{cm})$, number of leaves, nodes, branches, fruits, and fruit fresh weight. Dry matter accumulation was determined by measuring leaf, stem, root, and fruit dry weight.

\section{Data Analysis}

The data were subjected to Analysis of Variance (ANOVA) using the SAS software package (SAS Institute, Inc., Cary, NC) and means were separated using Duncan's Multiple Range Test at the 5\% level of significance.

\section{RESULTS AND DISCUSSION}

All fertilizer treatments tended to increase the vegetative growth of cucumber as indicated by the higher numbers of leaves and nodes, greater stem height and leaf area compared with the control even though the differences, most of the time, were not statistically significant (Table 1); this was apparently due to improved nutrition of the fertilized plants. Early application of fertilizer also tended to increase vegetative growth since the cucumber plant, as indeed most other plants, will concentrate assimilates to vegetative structures at the early stage and improved nutrition at this stage will tend to enhance stem elongation and leaf development (Salisbury and Ross 1992). The unfertilized plants had the lowest values in most of the vegetative parameters.

Once-over fertilizer application at $3 \mathrm{WAP}$ and split application at $3+6 \mathrm{WAP}$ produced plants with the highest number of leaves and branches while split application at planting +3 WAP produced plants with the largest leaf area.

Plants that received split applications of fertilizer at $3+6$ WAP had the highest dry matter accumulation in stem, root, and fruit and overall compared with other treatments. The unfertilized plants had the lowest dry weight of the various plant parts (Table 2). Plants fertilized once-over at planting produced significantly $(P=0.05)$ lower fruit dry weight compared with plants fertilized at $3+6$ WAP.

In terms of yield, plants fertilized at $3+6$ WAP produced the highest average number of fruits (3.25) and the greatest fruit fresh weight (554.4g plant ${ }^{-1}$ ) (Table 3). Apparently, this was because plants given this treatment were able to grow moderately vegetative at the early stage and utilized the second split application for fruit development. Plants fertilized only at planting had excessive vegetative growth, which was not ultimately translated into the highest yield. The application of fertilizer once-over at $6 \mathrm{WAP}$ produced the poorest plants compared with other fertilizer treatments, and not different from the control. This was due to the initial relatively lower vegetative growth in these plants before the entire fertilizer application during fruit development, implying lateness of fertilizer application.

This study showed that even though the split application at $3+6$ WAP produced the largest fruit dry weight, there was no clear difference in the fresh weight of plants due to the fertilizer treatments. The higher fruit dry weight implies higher accumulation of nutrients, vitamins and minerals and better fruit quality (Kano et al. 2001; Ruiz and Romer, 2002) as compared with fruit fresh weight which implies preponderance of water.

In conclusion, the results of this study showed that N-P$\mathrm{K}$ fertilizer (20:10:10) application is generally beneficial to the performance of cucumber as suggested also by Ekwu et al. (2000), Kano et al. (2001), Moreno et al. (2003) and Jasso-Chaverria et al. (2005). However, split application at $3+6$ WAP appears to be the best timing for fertilizer application in southwest Nigeria. Further work is, however, required to confirm the findings of this preliminary study.

Burkill, H. M. 1985. The useful plants of the West Tropical Africa. Vol. 1. Royal Botanical Garden, Kew, UK. 960 pp.

Drost, D. and Hefelbower, R. 2004. Cucumbers in the garden. Extension, Utah State University. [Online] Available: http:// www. Extension.usu.edu.cooperative/publications/ index.

Ekwu, L. G., Eselebe, H. O. and Okporie, E. O. 2000. Vegetative growth and yield response of cucumber to varying levels of nitrogen and phosphorus fertilizer in Southern Nigeria. Conference Proceedings of the Horticultural Society of Nigeria, 2000. pp. 117-120.

Jasso-Chaverria, C., Hochmuth, G. J., Hochmuth R. C. and Sargent, S. A. 2005. Fruit yield, size and color responses of two greenhouse cucumber types to nitrogen fertilization in perlite soilless culture. HortTechnology 15: 565-571.

Kano, Y., Goto, H., Fukuda, H. and Ishimoto, K. 2001. Relationship between the occurrence of bitter cucumber (Cucumis sativus L. cv. Kagafutokyuri) and total nitrogen, nitrate-N, amino acid-N and protein contents in the leaf and peel. J. Jpn. Soc. Hortic. Sci. 70: 438-442.

Messien, C. M. 1988. The tropical vegetable garden - Principles for improvement and increasing production with application to vegetables. MacMillan Publishers, London, UK. pp. 187-218.

Moreno, D. A., Villora, G. and Romero, L. 2003. Variations in fruit micronutrient contents associated with fertilization of cucumber with micronutrients. Sci. Hortic. 97: 121-127. 
Ruiz, J. M. and Romero, L. 2002. Relationship between potassium and nitrate assimilation in leaves and fruits of cucumber (Cucumis sativus) plants. Ann. Appl. Biol. 140: 241-245.

Salisbury, F. B. and Ross, W. R. 1992. Plant physiology. Wadsworth Publishers Inc., Belmont, CA. pp. 329-353.
SAS Institute, Inc. 1999. SAS software. Version 8.2. SAS Institute, Inc. Cary, NC. 